\title{
Patient safety: within the reach of the homeless?
}

\author{
Segurança do paciente: ao alcance das pessoas em situação de rua? \\ Seguridad del paciente: al alcance del habitante de la calle?
}

Felicialle Pereira da Silva'

ORCID: 0000-0002-2805-7506

Elizandra Cássia da Silva" ORCID:0000-0002-4785-4375

Adriana Lopes Ferreira"I ORCID:0000-0002-9566-3207

Iracema da Silva Frazão"' ORCID:0000-0002-4690-3753

'Centro Universitário Maurício de Nassau. Recife, Pernambuco, Brazil. "Hospital da Restauração. Recife, Pernambuco, Brazil. "'Universidade Federal de Pernambuco. Recife, Pernambuco, Brazil.

How to cite this article: Silva FP, Silva EC, Ferreira AL, Frazão IS. Patient safety: within the reach of the homeless?. Rev Bras Enferm. 2020;73(5):e20190114. doi: http://dx.doi.org/10.1590/0034-7167-2019-0114

Corresponding author: Felicialle Pereira da Silva E-mail: cialle@hotmail.com

EDITOR IN CHIEF: Dulce Aparecida Barbosa ASSOCIATE EDITOR: Hugo Fernandes

Submission: 02-19-2019

Approval: 10-01-2019

\section{ABSTRACT}

Objectives: to reflect on aspects related to homeless patients' safety. Methods: this is a reflective theoretical essay based on patient safety theories. Results: the patient safety culture has developed in the hospital care context and seeks to reduce adverse events in specific hospital settings. On the streets, there is evidence that many people suffer damage related to lack of access to health services, which contributes to undiagnosed or untreated diseases. To build the safety culture it is necessary to identify risks and errors in this scenario since health safety should not start only when hospitalizing an individual. Final Considerations: public policies for this population group need to be effective, as this issue should be a priority concern in health care to prevent harm and adverse events during care delivery.

Descriptors: Homeless Persons; Patient Safety; Primary Health Care; Public Policy; Patient Care Team.

\section{RESUMO}

Objetivos: refletir sobre aspectos relacionados à segurança do paciente que vive nas ruas. Métodos: ensaio teórico reflexivo baseado em teorias sobre a segurança do paciente. Resultados: a cultura de segurança do paciente se desenvolveu no contexto do cuidado hospitalar e busca da redução dos eventos adversos em áreas hospitalares específicas. Nas ruas, existem evidências de que muitas pessoas sofrem danos relacionados à falta de acesso aos serviços de saúde, o que contribui para que doenças não sejam diagnosticadas ou sigam sem tratamento. Para construção da cultura de segurança, se faz necessário identificar os riscos e os erros nesse cenário, pois a segurança em saúde não deve começar apenas quando um indivíduo é hospitalizado. Considerações Finais: políticas públicas para esse grupo populacional necessitam ser efetivas, visto que esta temática deve ser uma preocupação prioritária na assistência à saúde, a fim de prevenir danos e reduzir os eventos adversos durante a prestação de cuidados.

Descritores: Pessoas em Situação de Rua; Segurança do Paciente; Atenção Primária à Saúde; Política Pública; Equipe de Assistência ao Paciente.

\section{RESUMEN}

Objetivos: reflejar acerca de los aspectos relacionados a la seguridad del paciente que vive en las calles. Métodos: ensayo teórico reflexivo basado en teorías acerca de la seguridad del paciente. Resultados: la cultura de seguridad de la salud ha desarrollado en el contexto del cuidado hospitalario y en busca de la reducción de los eventos adversos en áreas hospitalarias específicas. En las calles hay evidencia de que muchas personas sufren daño en el sentido de falta de acceso a los servicios de salud, lo que contribuye para que enfermedades que no sean diagnosticadas o sigan sin tratamiento. Para la construcción de la cultura de seguridad, se hace necesario identificar los riesgos y los errores en este escenario, pues la seguridad en salud no debe empezar solamente cuando uno es hospitalizado. Consideraciones Finales: las políticas públicas para este grupo poblacional necesitan ser efectivas, visto que esta temática debe ser una preocupación prioritaria en la asistencia a la salud para prevenir daños y reducir los eventos adversos al largo de la prestación de cuidados.

Descriptores: Personas en Situación de Calle; Seguridad del Paciente; Atención Primaria a la Salud; Política Pública; Grupo de Atención al Paciente. 


\section{INTRODUCTION}

Patient safety has been a priority concern in care quality, for preventing damage and reducing adverse events during care delivery. The adverse event occurs from unwanted care-related complications that could result or result in unnecessary harm to the patient. Active failures to meet pre-established goals are related to "harm", however, it can also result from a lack of opportunity and a combination of inadequate care, whether inside or outside a hospital service ${ }^{(1)}$.

Thus, the Ministério da Saúde (Health Department), aligned with the World Health Organization (WHO), establishes for everyone the right to receive medical assistance safely at all health care points. Therefore, this includes homeless people who are characterized by a population in extreme poverty, with fragile disrupted family ties, and with non-existent regular conventional housing ${ }^{(2)}$. These rights are in the 'Programa Nacional de Segurança do Paciente' (National Patient Safety Program), which emphasizes that high-quality, safe health care should always be provided ${ }^{(3)}$.

In the context of hospital care, patient safety goals have been set to reduce adverse events in reasonably controlled environments. However, in Primary Health Care (PHC), despite the growing interest in the area, making health professionals aware of the importance of this practice is a significant challenge ${ }^{(4)}$. It is evident that the to provide quality healthcare depends on a variable of complex structural factors, on assistance, and behavioral processes that, when not contemplated, they distance the ideal care from that provided in the real world, favoring adverse events.

By comparing homeless health care with the Swiss cheese model propounded by James Reason, the vulnerabilities of the health system and the disruption of the individual's defenses lead to a path of failures. This represents wide fractures that, when aligned, result in harm to the patient. The Swiss Cheese Model is a theory widely used by patient safety professionals. It is an effective method for understanding complex events ${ }^{(5)}$.

This phenomenon creates considerations that need to be readjusted and developed through new tools and taxonomies in the patient safety field, focusing on individuals and their environment. In the streets, there is evidence that the homeless suffer damage from lack of access to health services, especially in $\mathrm{PHC}$ models, which leads to many illnesses not being diagnosed or remaining untreated. In this perspective, there is also the care fragility due to the scarcity of minimum resources and professionals to provide health care on the streets beside the lack of family support, which directly impacts on health and quality of life.

Then, this study was proposed by the need to reflect upon the context of patient safety in the street environment, since the risks involving homeless people are different from those observed in the hospital or PHC settings. Assuming that health security does not start only when an individual is hospitalized or treated at health centers, the lack of trained professionals and poor healthcare access are considered negligence.

Within this context, an analogy can be made reflecting on patient safety in PHC, as this should be the first route to health services. It is important to highlight that the terminology "patient safety" is connected to the concept of "reduction of unnecessary errors in healthcare", so it is necessary to include this term as a reference to homeless population care.
In this context, discussion points are presented to promote reflection about patient safety concerning the reality of those who live on the streets.

\section{PATIENT SAFETY: THOUGHTS ON HOMELESS' ACCESS TO HEALTH SERVICES}

The assessment of adverse events in primary care and their impacts on public health are a part of the Ministério da Saúde's (Health Department) priority research agenda. PHC should represent the first health access, as it allows people to be protagonists of their own care in their territory, prioritizing the ethical imperative that every demand, health need, or suffering must be accepted ${ }^{(6)}$. Thus, we understand that in PHC, individuals need to be motivated to engage their citizenship, therefore care practices, and management must be democratic and participatory, combined with team articulation. Hence, the needs of the homeless people must be the priority at this gateway.

Assuming that health is intersectoral, the safety of homeless patients is not a responsibility of the health sector only, given that the lack of opportunities, housing, employment, and income directly impacts their lives, which leads to living on streets as a means of survival. Consequently, this population is exposed to several advertises that cause harm, including infectious diseases, malnutrition, drug abuse, exposure to violence, mental and physical illness, and being deprived of basic needs, among many others.

The federal government issued the Decree No. 7,053 of 23 December 2009, establishing the National Policy for the Homeless Population. The policy principle proposes to guarantee life, and citizenship respect, and to ensure wide, simplified and secure access to services and programs that integrate public policies on health, education, social security, welfare, housing, security, culture, sport, leisure, employment, and income ${ }^{(2)}$.

About eight years after its creation, the policy has not been effective, since there are not enough actions aimed at the homeless population, which continues to grow, especially in large cities, perpetuating the severity of the problem. As healthcare benchmarks, there are the programs "Consultório de Rua" (Street Clinic- CR) and "Consultório na Rua" (Clinic on the street - CnR), implemented in 2010 and 2012, respectively. They embody strategic teams that aim to make healthcare accessible to homeless people through assistance in their own life context ${ }^{(7-8)}$.

The CR, coordinated by Mental Health, came to light focusing on the drugs issue during the clampdown on crack and other drugs. It aimed to increase access to care services and to improve care through street actions. The $\mathrm{CnR}$, coordinated by primary care, proposed to include integral health, changing strategic guidelines beyond the drug issue.

The $\mathrm{CnR}$ represents a major milestone in homeless people's care, as it aims to enable the reception and access to health actions that happen in the context of this population's life. Thus, these medical offices are composed of interdisciplinary health teams that work in the sanitary territories of Brazilian capitals, considering that urban centers concentrate the largest number of people living on the streets.

However, the practices of these teams are still incipient, as there are weaknesses that contribute to different and unarticulated 
forms of work. Among these weaknesses, there is the insufficiency of financial resources, the need for intensification of intersectoral actions, as well as instruments to evaluate the team's work. As a result, evidence shows that emergency roads remain the first route of contact between the homeless and health services.

\section{STRENGTHENING BARRIERS THAT MINIMIZE HEALTH DAMAGE TO HOMELESS POPULATION}

To reflect on the "Swiss cheese" theory, one of the main points includes understanding how homeless people are perceived by health professionals. Certainly, it does not differ from the general society view, causing such interpretation to be identified as one of the main barriers to the care of homeless people. Stereotypes and prejudice permeate this view, which leads this population to social invisibility and self-devaluation. Family relationships, in turn, are reported as strong triggers for living in the streets, while these bonds' absence contributes to increasing patient vulnerability $^{(9)}$.

Other striking features, such as displacement and the understanding of their own health-disease process, are open cracks, in which the individual does not realize the existence of health problems. In addition, lack of support and values constitute other barriers to health services access, as many of those who live on the street are treated and recognized as "hobos and dangerous" or "crazy, dirty and sick"(9).

The reality is that all situations involving street life create physical and mental health risks. However, they feel strong when signs and symptoms not infrequently go unnoticed and can become more severe, showing failures in homelessness or lack of care. Such isolated failures are combined with the vulnerability present in street life context and sometimes the negligence.

To build a healthcare safety culture, it is necessary to identify the risks and errors of this scenario in order to create teamwork and assessment of this work ${ }^{(1)}$. Therefore, knowing life trajectories and establishing intersectoral bonds and partnerships are important barriers to reducing damage. Health-related infections represent the first global challenge according to $\mathrm{WHO}$, which sets safe hand hygiene as the fifth healthcare security goal. However, we are talking about a population that generally does not have access to adequate hygiene or even sanitation ${ }^{(10)}$. In addition, some situations prevent correct identification and effective communication, which are the first and second international patient safety goals, respectively.

Citizenship rights realization represents an undeniable duty to the humans, while also means protection and care. It is a challenge to establish patient safety goals for people who live on the streets because the protection barriers of this group depend primarily on effective public policies to guarantee fundamental rights by social protagonism and the state.

\section{ACTION IN THE CONTEXT OF STREET PATIENT SAFETY: ADAPTATIONS AND CHALLENGES}

Safety targets for the care of street dwellers have not been included in the scope of patient safety, however, the reality of these people's living conditions shows damages that has a progressive impact over time since this population's access routes to health services are mostly emergency, after long illness processes. The patient safety research cycle advises that it is necessary to understand the causes of this damage since it is considered that, by analyzing the root cause, it is possible to rethink effective practices both to prevent the homeless from being harmed and, first and foremost to promote their health ${ }^{(1)}$.

It is understood that in the street life scenario the concept of patient safety becomes even more complex, therefore it requires tools that can be adapted to this environment, in which the care focus centers not only on the homeless people but in their life trajectory, including family and community. The difficulty of homeless people regarding access to health services has been highlighted in studies with this population, for which barriers to health services are universal, that is, both nationally and internationally.

Thus, expanding access and improving the Primary Care actions resolubility together with $\mathrm{CnR}$ teams should be priorities, considering that these devices represent a significant advance in care directed to the homeless population, as they understand that such social group has different demands beyond the social or health exclusive ones.

The street patient safety agenda is a challenge that requires reflection on the ideal and real care level, and the adaptation and response to the needs of this population through the monitoring of specific public policies. Patient safety protocols should be converted into goals for the empowerment of the homeless. This adaptation should involve both cohesive communication and effective program coordination, as well as set up health professionals involved in care for people who live on the streets in the main roles.

\section{Study limitations}

Due to the type of study presented, the described reflections grounds on the researchers' professional experience and the theories that underlie patient safety, considering that this field is not yet covered in all dimensions of care.

\section{Contributions to the nursing field and public health}

The patient safety culture proposes the undeniable relevance of preventing adverse events in health care. In this sense, studying the theme of homeless people care was interesting and thought provoking. It is considered important that health professionals study this topic, which is still incipient. There is a need for care locus to be legitimately recognized and considered deserving of effective public policies. For nursing, as a profession specialized in human care, it is important to reflect upon this field space in the street life scenario. This space is not yet well established in the composition of CnR strategic teams for integral care for the homeless population.

\section{FINAL CONSIDERATIONS:}

This study aimed to reflect on the patient safety subject directed to those who live on the streets. From this perspective, 
this should be a concern for all healthcare workers because of the potential to provide safe and qualified care. Therefore, it is necessary to expand the reflection that health security should not start only when hospitalizing an individual.

It is evident that all care scenarios must be rethought and contemplated. In this sense, public health policies are important instruments that guide care, making it essential to monitor health devices, such as the $\mathrm{CnR}$, regarding structure, access, and professionals' quantity, and profile. Knowing and assisting those living on the street requires interdisciplinary and transdisciplinary work, with social participation and strengthening of public policies, so that this vulnerable population becomes visible to inclusive policies.

Investments in more studies involving this theme are necessary to enable a different perspective on the theoretical reference of patient safety, considering those who live on the streets. Whether they are called individuals, clients or patients because, regardless of nomenclature, everyone deserves respect and safe health care.

\section{ERRATUM}

Article "Patient safety: within the reach of the homeless?", with number of DOI: http://dx.doi.org/10.1590/0034-71672019-0114, published in the journal Revista Brasileira de Enfermagem, 73(5): e20190114, on page 1:

Where to read:

\section{Corresponding Author:}

Felicialle Pereira da Silva

E-mail: carlaenfermagem@yahoo.com.br

Read:

\section{Corresponding Author:}

Felicialle Pereira da Silva

E-mail: cialle@hotmail.com

\section{REFERENCES}

1. Vincent C, Amalberti R. Cuidado de saúde mais seguro: estratégias para o cotidiano do cuidado. Proqualis [Internet]. 2016[cited 2019 Jun 20]. Available from: https://proqualis.net/livro/cuidado-de-sa\%C3\%BAde-mais-seguro-estrat\%C3\%A9gias-para-o-cotidiano-do-cuidado

2. Ministério da Saúde (BR). Decreto n॰ 7.053 de dezembro de 2009. Política Nacional para a População em Situação de Rua; 2009.

3. Reis GAX, Hayakawa LY, Murassaki ACY, Matsuda LM, Gabriel CS, Oliveira MLF. Nurse manager perceptions of patient safety strategy implementation. Texto Contexto Enferm [Internet]. 2017[cited 2019 Jun 20];26(2):e00340016. Available from: http://www.scielo.br/pdf/tce/ v26n2/0104-0707-tce-26-02-e00340016.pdf

4. Mesquita KO, Silva LCC, Lira RCM, Freitas CSL, Lira GV. Patient safety in primary health care: an integrative review Cogitare Enferm[Internet]. [cited 2019 Jun18];21(2):01-08. Available from: http://docs.bvsalud.org/biblioref/2016/07/684/45665-182025-1-pb.pdf

5. Fernandes LGG, Tourinho FSV, Souza NL, Menezes RMP. Contribuição de James Reason para a Segurança do Paciente: reflexão para a prática de enfermagem. Rev Enferm UFPE. 2014;8(supl.1):2507-12. doi: https://doi.org/ 10.5205/reuol.5927-50900-1

6. Ministério da Saúde (BR), Gabinete do ministro. Portaria n² 2, de 28 de setembro de 2017. Consolidação das normas sobre as políticas nacionais de saúde do Sistema Único de Saúde[Internet]. Diário Oficial da União: República Federativa do Brasil; 2017 [cited 2019 Jun 20]. Available from: http://bvsms.saude.gov.br/bvs/saudelegis/gm/2017/prc0002_03_10_2017.html.

7. Hino P, Santos JO, Rosa AS. People living on the street from the health point of view. Rev Bras Enferm [Internet]. 2018 [cited 2019 Aug 10];71(Suppl 1):684-92. Available from: http://www.scielo.br/pdf/reben/v71s1/0034-7167-reben-71-s1-0684.pdf

8. Ministério da Saúde (BR). Portaria no 122 de 25 de janeiro de 2011. Define as diretrizes de organização e funcionamento das equipes de Consultório na Rua. Diário Oficial da União; 2012.

9. Paiva IKS, Lira CDG, Justino JMR, Miranda MGO, Saraiva AKM. Homeless people's right to health: reflections on the problems and componentes. Ciênc Saúde Coletiva [Internet]. 2016 [cited 2019 Aug 10];21(8):2595-606. Available from: http://www.scielo.br/pdf/csc/ v21n8/en_1413-8123-csc-21-08-2595.pdf

10. Agência Nacional de Vigilância Sanitária (ANVISA). Assistência segura: uma reflexão teórica aplicada à prática [Internet]. Brasília: ANVISA; 2013 [cited 2019 Apr 7]. Série Segurança do Paciente e Qualidade em Serviços de Saúde. Available from: https://www20.anvisa.gov.br/ segurancadopaciente/index.php/publicacoes/category/livros 